\title{
Analysis of Individual Investment on Higher Education based on the Net Present Value Method
}

\author{
Hou Haixia ${ }^{*}$ \\ College of Business Administration, Henan Institute of Engineering, Zhengzhou, Henan, 451191, China
}

\begin{abstract}
Education investment is the main form of human capital investment, especial higher education investment. The thesis mainly made an empirical analysis of individual investment on higher education by using the net present value method in financial management. First, we analyze the cost proportion of higher education investment, including direct cost and indirect cost. The income of higher education mainly includes economic benefits. On basis of this, we establish net present-value economic model of personal higher education investment to quantify and measure the investment ration economic effect, Finally, the conclusion that it is feasible for individuals to invest on higher education is drawn by carrying on the empirical analysis of actual cases.
\end{abstract}

Keywords: Higher education invest, investment cost, investment profit, net present-value.

\section{INTRODUCTION}

In recent years, with the gradual increasement of higher education enrollment scale, the high school students have more chances to go to universities. But meanwhile the students face the situation that the education fees keep increasing, the universities increase enrollment year by year, and the employment situation is becoming more and more serious, the acceptance and investment on higher education doesn't mean a good return.

Now from the perspective of individual investors, by using the net present value method in financial management, we build an economic net present value model of individual investment in higher education. The higher education personal investment in the field of micro has carried on the empirical analysis, in order to draw some inspiration and provide effective reference for the higher education investment [1].

\section{INDIVIDUALS RECEIVING HIGHER EDUCATION OWNS THE NATURE OF INVESTMENT}

From the perspective of individual investors the acceptance of higher education, is a long-term investment plan. Individuals receive higher education and invest on higher education to acquire all kinds of knowledge, professional skills, etc., so as to furtherly get more higher life satisfaction in the future, or employment to increase personal income as a laborer's future. Higher education expenditure in the nature of investment at present has formed a consensus. Along with the development of our country's economy and education, the implementation of the reform of education system, the pattern has preliminary formed in mainly financial education funds together with other education funds and complementary raising education funds with various channels. Among them, families and individuals has become one of the main body of higher education investment, it is very important. But due to the lagging of ideas, and itself from the limitation of education level, for all the costs of higher education and higher education, family members of large families and individuals in China can bring its expected return lack of enough understanding. And risk of investment in higher education is hard to understand, it is only for the opportunity increasement and employment pressure todrive to receive higher education enthusiasm and invest blindly. But after investment, under the increasing employment pressure, people tend to produce all sorts of doubts year by year [2].

As a human capital investment behavior, personal investment on higher education will inevitably have costs, benefits and risk factors. Study of higher education personal investment value, helps to promote family and personal reason of higher education investment, improves the efficiency of higher education personal investment, helps individuals to gain more higher education investment returns. And the net present value method in the financial management is a more scientific and easy methods to evaluate investment scheme. NPV (Net Present Value) is an investment of future cash flows of the difference in Value between Present Value and project investment cost. Net present value method is to use the net present value index as a long-term investment evaluation using standard methods. The method is to use the total amount of net cash benefits present value and net cash investment to calculate the net present value, then evaluate investment scheme according to the size of the net present value. If the net present value is positive, the investment plan is acceptable; Net present value is negative, the investment plan is unacceptable. The greater the net present value is, the better the investment plan will be. Below are based on detailed analysis, the net present value method in financial management to higher education personal investment [3]. 


\section{THE PERSONAL COST ANALYSIS OF HIGHER EDUCATION INVESTMENT}

Education investment refers to the input field of education, to cultivate different proficiency of backup of labor and specialized personnel, in order to improve the level of their intelligence and practice ability of currency. According to the views of human capital theory, whether individuals invest on education must consider cost of investment and education investment returns, and make a decision through the balance analysis and comparison. Higher education cost refers to the individuals for their own advanced education costs. It mainly includes the monetary and non-monetary costs [4].

\subsection{Monetary Cost}

Monetary cost consists of two parts: direct costs and indirect costs or the opportunity cost.

Direct costs, Direct costs covers higher education input. It mainly includes tuition, fees, books and other school supplies such as stationery, and because of the extra spending life at university such as room and board, transportation, communications, etc. Basic daily life costs should not be credited to direct costs because if you don't accept higher education, this part of cost will stilloccur, the selected below is just a part of everyday life cost of additional spending.

Indirect costs, also the opportunity cost. Because of receiving higher education, people can not participate in the labor market work and lose the possibility of income. For example, the opportunity cost of going to college is graduating from high school will have a job. Practice has proved that the most important factor affecting the individual higher education investment is not direct costs, but the opportunity cost. Opportunity cost is an important part of the human capital investment cost, when choosing higher education many people hesitate, opportunity cost is one of the very important part of the reasons. At the same time when the unemployment rate increase, you will see the demand of higher education, it is also a very good example.

\subsection{Non-Monetary Cost}

Generally speaking, non-monetary cost refers to the psychological cost because of the advanced education. Due to the non-currency cost to be a kind of subjective feeling, it is difficult to quantify, so the analysis of general analysis omitsnon-monetary costs. When researching by using net present value method also omit non-monetary cost, mainly consider the monetary cost [5].

\section{THE PERSONAL BENEFIT ANALYSIS OF HIGHER EDUCATION INVESTMENT}

Personal benefits of higher education investment mainly includes economic benefits and non-economic benefits or spirit returns.

\subsection{Economic Benefits}

Higher education investment of personal economic income is expected to accept higher education after a higher income, but the future possible higher income must be able to compensate the cost of investment.
Individual higher income in the future. In general, the individual income level is closely relative to a fixed number of year of education, the longer the fixed number of year, the higher expected income level. In China, professor Chen Liangkun from Beijing Normal University was conducted a study research in 1992. Income and level of education has obvious relationship, the study shows that the education level increases each year, the annual average income increases of 104 yuan. This part is very important part of personal economic income. It will consider individual higher future income part when using net present value method research.

A reasonable personal future spending. It is generally believed that a person with higher education arranges personal and family expenses better than people without higher education.

More healthy body in the future. People with higher education will have more knowledge of science, so that they can better pay attention and protects oneself and family member's health. Social and economic statistics show that in personal economic income and health condition of the same circumstances, education level and health status were positively correlated.

Personal future larger professional mobility. People with higher education may have more chance of changing careers, easier to find more superior work in the Labour market conditions, have a greater ability to adapt work, or to adapt to the process and the change of industrial structure, master new technology and new knowledge, and so on. In a bad economy, facing unemploment people are often in a more advantageous position [6].

\subsection{Noneconomic Gain}

Noneconomic gain or spiritual benefits including higher education can improve one's social status, people's choice of vocational ability and satisfaction. People's appreciation ability to work, life and art is greatly increased, even more deeply understanding the meaning of life, and so on. Due to the economic gain which is hard to get accurate measurement, we will also not analyze it.

\section{THE NET PRESENT VALUE CALCULATION MODEL OF HIGHER EDUCATION INVESTMENT}

Under the condition of market economy, after receiving the compulsory education, people will be faced with a variety of choices, they can immediately go into the Labour force, also continue to learn, as mentioned in the university, to a higher level of human capital investment. When making this choice, economic factor is the most important factor to consider. Overall, when the total revenue is more than the total cost of receiving higher education, people will choose to continue their higher education investment.Due to that the main body of human capital investment is a person, therefore, when analyzing the costs and benefits, people does not take into account the social investment and benefits $[7,8]$.

Education investment decision model can be expressed in Fig. (1).

In Fig. (1), starting from A curve representing 18 years old to go to college after graduating from high school, the 


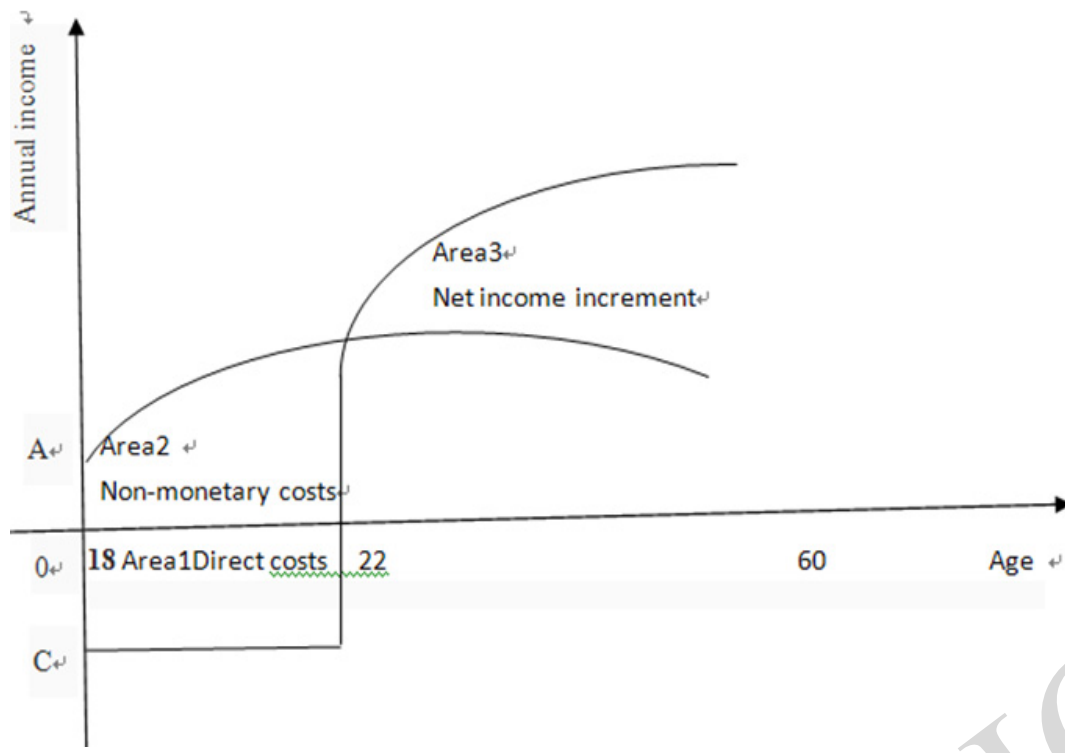

Fig. (1). Education investment cost and profit model.

students enter the Labour market to seek employment the lifetime income curve. By a representative of the $\mathrm{C}$ as a starting point of curve after graduating from high school to go to college first, and then the students enter the Labour market to seek employment the cost - income curve (assuming they job immediately after graduation).

Figure in the areas under the horizontal axis of one of the direct costs during the period of university, on behalf of the area on the horizontal axis 2 give up during the period of university on behalf of the income, namely the indirect costs. The sum of the zone 1 and zone 2 area, is the personal total cost or total investment at university. Area 3, said net income increment can be obtained after graduating from college, the university seeking employment can earn back on lifetime income, better than no college directly work can make the difference between the lifetime earnings. In this case, the assumption is that workers can work to 60 years old, and not to consider various benefits after 60 years of age.

We can see from the table, the spending for 4 years, and benefits of 38 years $(60-22)$. Net present value will consider the time value of money, so the decision must choose basis points, at the same time the basis points are calculated respectively when the present value of the costs and benefits, and compares to calculate the net present value of higher education investment.

Consider 22 to basis points, then the individual university education investment for net present value is

$$
\mathrm{NPV}=\sum_{n=0}^{38} \frac{E_{n}}{(1+i)^{n}}-\sum_{m=1}^{4} C_{5-m}(1+i)^{m}
$$

Among them: $\sum 0-\sum 38$ from the age of 22 to 60 years old may obtain annual income increment due to accept university education, sum equal to the area of the area 3 in Figs. (1.C1-C4) respectively from 18 to 22 years old to accept various cost of university education, namely, the sum of direct cost and opportunity cost, the sum is equal to the Fig. (1) in the area of the zone 1 and zone 2 combined.
By going through investigation, analysis, prediction, we can conclude about (desired) cost and profit, on the plug type can get higher education personal investment in net present value (NPV). If NPV $>0$, the personal higher education investment is economically feasible; If NPV $<0$, then accept the university education is not the economy, we should obtain employment; If NPV $=0$, receiving higher education is unnecessary.

\section{AN EMPIRICAL ANALYSIS OF THE HIGHER EDUCATION PERSONAL INVESTMENT BASED ON NET PRESENT VALUE METHOD}

Choose a practical case for studying the empirical analysis. Li mou, male, Guangxi examinee, on August 20, 2013 he got the admission notice of a university of Henan. Indicated on the notice, the tuition fee is 3700 yuan/year, accommodation, 800 yuan/year, length of schooling is 4 years. Otherwise a job waiting for him.To work in Guangzhou, the average monthly income is 4000 yuan/month with free accomodation and meals.

Calculations suggest. To ensure that the measure of the costs and benefits in September 2013 and to the university period when comparing, so you need to put him on the costs and benefits of the university of is the present value of the converted into September 2013. In order to calculate the real, it has the certain reality guiding sense, China's CPI up spoke to $2.6 \%$ year-on-year in 2013 , in 2013 China's GDP growth rate is $7.7 \%$, so that it is better to choose $10 \%$ as the discount rate.

\subsection{Cost Analysis}

Direct cost (the actual cost): daily living calculated at 10 months, 800 yuan a month. Schedule of college costs are shown in Table 1. Total direct cost present value of four years university $(12636+11487+11345+10313=45781 \mathrm{RMB})$.

The opportunity cost. In college because of giving up the income of work. Assume that working in guangdong, the first year's salary is 4000 yuan/month, the award is 1000 
Table 1. Schedule of college expenses unit:yuan.

\begin{tabular}{|c|c|c|c|c|c|c|c|}
\hline & Tuition and Fees & Books & Accommodation & $\begin{array}{c}\text { Daily Cost of } \\
\text { Living }\end{array}$ & Transportation & Total Present Value \\
\hline \hline $\begin{array}{c}\text { Freshman } \\
(2013,9-2014,8)\end{array}$ & 3700 & 400 & 800 & 8000 & 1000 & 13900 & 12636 \\
\hline $\begin{array}{c}\text { Sophomore } \\
(2014,9-2015,8)\end{array}$ & 3700 & 400 & 800 & 8000 & 1000 & 13900 & 11487 \\
\hline $\begin{array}{c}\text { Junior } \\
(2015,9-2016,8)\end{array}$ & $\begin{array}{c}4500(800 \text { yuan for } \\
\text { master degree } \\
\text { applicance) }\end{array}$ & $\begin{array}{c}800 \text { (master degree } \\
\text { applicance mate- } \\
\text { rials) }\end{array}$ & 800 & 8000 & 1000 & 15100 & 11345 \\
\hline $\begin{array}{c}\text { Senior } \\
(2016,9-2017,8)\end{array}$ & 3700 & 400 & 800 & 9000 & 1200 & 15100 \\
\hline
\end{tabular}

Table 2. The Income giving up table unit:yuan.

\begin{tabular}{|c|c|c|}
\hline Time & The Possible Income & 2013 Present Value \\
\hline \hline $2013,9-2014,8$ & 49000 & 44546 \\
\hline $2014,9-2015,8$ & 50700 & 41898 \\
\hline $2015,9-2016,8$ & 52400 & 39368 \\
\hline $2016,9-2017,8$ & 54100 & 36950 \\
\hline Total & 206200 & 162762 \\
\hline
\end{tabular}

yuan, yearly increasement is 100 yuan/month, year-end bonuses increase by 500 yuan each year. First year opportunity cost is 49000 yuan, the present value is 44546 yuan; In the second year, it is 50700 yuan, the present value is 50700 yuan; In the third year it is 52400 yuan, the present value is 52400 yuan; In the fourth year it is 54100 yuan, the present value is 36950 yuan. After four years it amounted to 206200 yuan, the equivalent cash value is 162762 yuan in 2013. So the total cost of the college is: $\$ 45781+162762=45781$. See Table 2.

\subsection{Benefit Analysis}

Assuming that he can get a medium scholarship every year 3000 yuan/year, freshman part-time income is 4000 yuan, sophmore, junior, senior part-time earns is up to 4000 yuan. The freshman scholarship and part-time income is 7000 yuan, present value is 6364 yuan;Sophomore year income is 7000 yuan, the present value is 5785 yuan. Junior year income is 7000 yuan, the present value is 5259 yuan. The senior year income is 7000 yuan, the present value is 4781 yuan. Through calculation, the various income during the university is 28000 yuan, the discount cash value of 2013 years is 22189 yuan. See table 3 .

For income after graduation work, the income of high school graduates just started to rise, but it is impossible to rise too fast and too high. But the income of college graduates starts better than high school graduates, and at the same time, the rate of growth will be higher than that of high school graduates, the final level will be higher than that of high school graduates. We expect high school graduates and university graduates of compensation calculated separately to the retirement age 60. Assume that high graduate and graduated from the university's career development is as follows: assuming that graduated from high school to work in Guangdong, four years after 22 years old, when monthly wages is 4400 yuan, the average annual increase of 100 yuan a month, after 26 years old wage no longer increases, the monthly salary is 4800 yuan, up to 35 years old to workshop director, monthly salary of 7000 yuan, it no longer changes. Assume direct employment in Guangzhou universities, Guangdong area salary survey report in 2013-2014, from the year of 2013 different degree pay distribution table saw, undergraduate average monthly salary is in 7000 yuan. So selecting monthly salary 000 yuan, the average annual increase of 100 yuan a month, after a promotion to 30 years old, direct rose to 10000 yuan a month, the average monthly wage increase of 100 yuan, after 40 years of age pay no longer increases. The income of high school are shown in Table 4. Income of graduates from the university is shown in Table $\mathbf{5}$.

Through the calculation of income of high school graduation in 2013, the total present value is 400979 yuan, in 2013 graduated from the university income present value amounted to 690178 yuan. College graduates get more income present value than high school graduates:RMB $690178-400979=400979$. The total revenue for the university education: $22189+289199=22189$ yuan.

\subsection{The Costs And Benefits Balance Analysis}

According to the above detailed calculation, the total cost is 208543 yuan, of the university of total income of 311388 
Table 3. Scholarship and part-time income during the university unit:yuan.

\begin{tabular}{|c|c|c|c|c|}
\hline Time & Scholarship & Part-time income & Total & 2013 Present value \\
\hline \hline Freshman $(2013,9-2014,8)$ & 3000 & 4000 & 7000 & 6364 \\
\hline Sophomore $(2014,9-2015,8)$ & 3000 & 4000 & 7000 & 5785 \\
\hline Junior (2015, 9-2016, 8) & 3000 & 4000 & 7000 & 5259 \\
\hline Senior (2016, 9-2017,8) & 3000 & 4000 & 7000 & 4781 \\
\hline Total & 12000 & 16000 & 28000 & 22189 \\
\hline
\end{tabular}

Table 4. The income of high school graduates unit:yuan.

\begin{tabular}{|c|c|c|c|c|c|c|}
\hline Age & $\mathbf{2 2}$ & $\mathbf{2 3}$ & $\mathbf{2 4}$ & $\mathbf{2 5}$ & $\mathbf{2 6 - 3 4}$ & $\mathbf{3 5}-\mathbf{6 0}$ \\
\hline \hline Income & $4400 \times 12$ & $4500 \times 12$ & $4600 \times 12$ & $4700 \times 12$ & $4800 \times 12 \times 9$ \\
\hline $\begin{array}{c}2013 \text { Present } \\
\text { Value }\end{array}$ & 32784 & 30483 & 28329 & 26310 & 140682 \\
\hline
\end{tabular}

Table 5. Income levels of university graduates unit:yuan.

\begin{tabular}{|c|c|c|c|c|c|c|c|c|c|c|}
\hline Income & $7000 \times 12$ & $7100 \times 12$ & $7200 \times 12$ & $7300 \times 12$ & $7400 \times 12$ & $7500 \times 12$ & $7600 \times 12$ & $7700 \times 12$ & $10000 \times 12$ & $10100 \times 12$ \\
\hline Age & 32 & 33 & 34 & 35 & 36 & 37 & 38 & 39 & $40-60$ & total \\
\hline Income & $10200 \times 12$ & $10300 \times 12$ & $10400 \times 12$ & $10500 \times 12$ & $10600 \times 12$ & $10700 \times 12$ & $10800 \times 12$ & $10900 \times 12$ & $11000 \times 12 \times 21$ & \\
\hline
\end{tabular}

yuan, with a $311388-208543=208543$ yuan, net present value is far greater than zero, obviously yield is much greater than the investment cost, thus can be judged from the economic choice of receiving higher education college is feasible.

Model in this paper is intended to set out from the current employment situation, for the upcoming and ongoing people provide some useful reference of higher education investment. In the investment income of comparison analysis using the model, we must pay attention to do the following: First of all, to conform the development of society, the individual ideals closely linked to social progress. People should choose a few professional social demands as a professional higher education investment, in this way we can graduate with better and faster in employment and career development. Second, the human capital investment to fully realize the self ability factor, discreet choice on the basis of personal preference. Selection of the right direction, so as to foster strengths and circumvent weaknesses, success probability is bigger, income is also higher. Moreover people should also consider the actual capacity of each family, do their higher education investment analysis, choose the optimal solution, do not make "learned from poverty". Finally, since chosing the higher education investment, people should have correct study attitude, set up the correct learning concept, adopt the suitable study method, really learn some knowledge, and improve their professional skills. Have learned something, to practice, so that his career is to forecast the direction of the smooth development, to achieve the expected benefits, but personal higher education investment is a truly viable solution.

\section{CONFLICT OF INTEREST}

The authors confirm that this article content has no conflict of interest.

\section{ACKNOWLEDGEMENTS}

This work is supported by the 2015 Henan Provincial key scientific research project of university, China (No. 15B630003).

\section{REFERENCES}

[1] W. Schultz, "the role of human capital investment, education and research" The commercial press, 1990.

[2] X. Zeng, "labor economics", Fudan university press, 2010

[3] The National Center for Public Policy and Higher Education (2002). Losing Groud, A National Status Report on the Afford ability of American Higher Education.

[4] Z. Liu, "Existing problem and countermeasure research of Chinese university personnel training mode under the condition of market economy," Higher Education Research, vol. 02, 2011. 
[5] B. Yang, "Personal cost and benefit analysis of higher education," People's BBS, vol.17, 2011.

[6] K. Xu, "Human capital cost and benefit analysis of the stage of higher education personal investment," Contemporary Economic Studies, vol. 5, 2011.
[7] hskkk.blogchina.com/viewdiary.17373231.htm129K 2007.

[8] G. Li, and X. Gu, "Rural students receiving higher education personal cost and benefit analysis - investigation and study basing on Haibei, Huairen, Shanxi province," Education research, vol. 07, 2012.

(C) Hou Haixia; Licensee Bentham Open.

This is an open access article licensed under the terms of the Creative Commons Attribution Non-Commercial License (http://creativecommons.org/licenses/by-nc/3.0/) which permits unrestricted, non-commercial use, distribution and reproduction in any medium, provided the work is properly cited. 